\title{
AMICULUM IUNONIS: JUNO AND THE FEAST OF THE LUPERCALIA
}

\begin{abstract}
Summary: This article focuses on the possible connections which can be established between the Roman goddess Juno as the protector deity of marriages and married women and the rites and rituals associated with the sacred feast of the Lupercalia. The role of other Italic gods associated with these sacred ceremonies is also analyzed, such as the rustic god Faunus, as well as Jupiter, Mars, and Romulus-Quirinus (albeit in secondary roles; for example, the name Luperci given to the young Roman men involved in the ritual flogging of the Roman women of fertile age is linked with lupus, the Latin name of the wolf, animal sacred to the god Mars and forever bound to the Twins Romulus and Remus, the mythical and heroic founders of Rome). The amiculum Iunonis or the garment of Juno is in fact the name given to the ritual objects used by the Luperci in the act of symbolic fecundation of the Roman young women, namely the leather thongs carved out of the skin of a sacrificed goat. The he-goat (Latin hircus) is also connected with the ancient Roman and Latin god Faunus (the Italic divine counterpart of the ancient Greek Пôv). As a final acknowledgment, I hereby thank Professor Attilio Mastrocinque who had the idea of this study and whose book revealed to me the hidden links between Juno, Bona Dea, and the feast of the Lupercalia, normally associated with the god of wild nature, Faunus-Pan. I owe also a debt of gratitude to the patience and unremitting help of Professor Patricia Johnston, whose observations greatly improved my conclusions.
\end{abstract}

Key words: Lupercalia, Juno, Amiculum, Faunus, Luperci

The main idea of this short article is to underline the role and function of the goddess Juno during the Roman feast of the Lupercalia. We do not know many things about this festival, except that it was a fertility ritual taking place each year during the Ides of February (13 ${ }^{\text {th }}$ of February, according to our modern Calendar) and that the patronizing deities were Faunus-Lupercus, Mars, and possibly also Juno (Iuno). Its very name, Lupercalia, refers to the name of the wolf (in Latin lupus), an animal consecrated to 
Mars, the Roman god of war and protector of agricultural fields. ${ }^{1}$ The Lupercal(e) was the natural cave in the slope of the Palatine hill, facing the Tiber, where the river's stream floated the basket with the baby twins Romulus and Remus (the sons of the god Mars and of the Vestal Rhea Silvia) and where the she-wolf (lupa), the animal sacred to Mars, suckled the two children and protected them from harm's way (Ovid, Fasti II 381-388).

We begin our incursion in this difficult field of investigation by quoting a passage from Paulus the Deacon's (the Germanic Lombard scholar Warnefried/Winfrid from the $8^{\text {th }}$ and early $9^{\text {th }}$ century after Christ who has been an active part of the Carolingian Renaissance and a prominent member of Charlemagne's Academia/Schola Palatina) abridgment of the work of the $2^{\text {nd }}$ century CE Roman grammarian Sextus Pompeius Festus, who, in his turn abridged the Latin linguistic treaty De significatu verborum of the Augustan-age scholar Marcus Verrius Flaccus. ${ }^{2}$ The text of the fragment runs as follows:
februarius mensis dictus, quod tum, id est extremo mense anni populus februaretur, id est lustraretur et purgaretur, vel a Iunone Februata, quem alii Februalem, Romani Februlim vocant, quod ipsi eo mense sacra fie- bant, eiusque feriae erant Lupercalia, quo die mulieres februabantur a Lupercis amiculo Iunonis, id est pelle caprina; quam ob causam is quoque dies februatus appellabantur (Paul. Fest. 75 L).

My rough English translation of this text is the following:

The month is called February (Februarius), either because in the last month of the year the people was purified (februaretur), meaning that people underwent a purification (lustraretur) and was therefore (ritually) cleansed or purged (purgaretur), or from Iuno Februata, who is called Februalis by some and by the Romans is named Februlis, because they accomplished

${ }^{1}$ The rites of the Lupercalia, the calendar-dates, and the Roman deities (and their Greek counterparts) associated with them are mentioned in Ovid, Fasti II, 267, 303, 331, 359, 381, 425, and 453: here we read about the tutelar deities of the Lupercalia, namely Faunus (identified by the Roman poet with the ancient Greek god of wild nature, Pan/П人̂v), but also Juno (in her capacity of Iuno Lucina, the Roman goddess protector of women in childbirth). Ovid also mentions Heracles/Hercules, as well as the Pelasgians and Arcadians (of king Evander) that once dwelled on the Palatine hill, but also Rhea Silvia (and by implication the warlike god Mars), the Founder Twins of Rome (Romulus and Remus); and he mentions also Jupiter (Iuppiter) the god of storms, thunderbolts, and heaven (who replaces the old Roman god of the sky representing the Italic counterpart of the ancient Greek god Oủ Qovós, possibly related both from a mythological point of view and by etymology with the Vedic Indo-Aryan god Varuna), Aeolus the god of

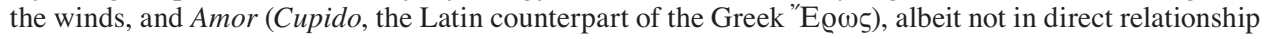
with the Lupercalia. There is also the problem of the Iuno Februa (or Februata), an aspect or hypostasis of Juno as a purification deity (the name Februarius mensis originates from the Latin verb februo, februare, "to purify, to make clean" in a ritual form). Ovid also mentions the god Quirinus as the deified Romulus and the etymology of Quirinus coming either from the Quirites (Cives Romani) or from the name of the Sabine stronghold of Cures. The Lupercalia are also connected by Ovid with the rape of the Sabine women by Romulus' companions (the Luperci as a reminder of Romulus' war band of comrades). DuMÉZIL 1993, 33-36 (esp. 34-35); DuMÉZIL 1998, passim; DuMÉZIL 1999, 14-15.

${ }^{2}$ https://en.wikipedia.org/wiki/Paul_the_Deacon. 
sacred rites (sacra fiebant) in that month, and the Feasts (eiusque Feriae) dedicated to this goddess (i.e. Juno Februata, Februalis, or Februlis) were the Lupercalia; on that particular day the women (mulieres) were ritually purified (februabantur) by the Luperci with the garment of Juno, that is, with the skin of a goat (amiculo Iunonis, id est pelle caprina); because of that, this day was called purified (dies februatus).

Closely looking at this text, we immediately see the connection between the rituals of purification of the ancient Romans that took place in February, the women (presumably young nubile girls and young married women of fertile age), and the goddess protecting marriages, gravidity, and child birth, Juno (also known under the epithets of Februata, Februalis, or Februlis). The young men involved in this ritual of purifying the Roman womenfolk of nubile and fertile age are called the Luperci (a name clearly related to Faunus Lupercus, the old Latin god akin to the ancient Greek deity of wild nature, Pan) and the ritual instrument used for purifying the women is a garment or belt (amiculum) made out of goat skin (pelle caprina, in the Ablative case in our text). The day of the feasts of Lupercalia, when this peculiar rite was performed, is called dies februatus (a purified/purifying day) in our text. In the following pages we shall also analyze the testimonies of other Latin writers about Juno and the feasts of the Lupercalia, such as Ovid, Arnobius, and Macrobius.

The next Latin and ancient Roman writer (after Marcus Verrius Flaccus) who wrote about the Lupercalia and the goddess Iuno (as well as about the Faunus Lupercus) was Ovid. In his poem entitled Fasti he gives a lot of information about the performance of Roman religious feasts during the year. The very significance of the name of February (Februarius mensis) comes, according to Ovid, from Februa, which means "ceremonies or rituals of purification", ritual cleansing of the people and appeasement of the gods: "Februa Romani dixere piamina patres" to quote Ovid's very verse. ${ }^{3}$ Ovid thinks therefore that februa means piamina of the ancient Romans or Romani patres (in this verse, februa taken as noun means ceremonies or rites of purification, piamina) and these rituals are intended to placate the wrathful outbursts of the gods (seen as unpredictable divine powers). My English translation of this verse is the following: "the Roman Forefathers named februa the ceremonies for appeasing (piamina) the gods and purifying the people". The name februa, according to the subsequent verse, was given to pieces of wool (lanas) sought by the Pontifices from the Rex (presumably the Rex sacrorum or Rex sacrificulus in the Republican Rome; during the Roman monarchic age, the Roman Rex was also the supreme head of the state religion) and the Flamen (presumably the Flamen Dialis, the chief priest of Iuppiter; Ovid does not specify here who the flamen involved in this rite was; due to the fertility ritual, it would have also been possible that the Flamen Martialis or the Flamen Quirinalis were involved,

${ }^{3}$ Ovid, Fasti II 19. I have used here the electronic edition: Ovid: Fasti II - The Latin Library www. thelatinlibrary.com/ovid/ovid.fasti2.shtml 
as priests to Mars and Quirinus respectively). ${ }^{4}$ In the ancient Latin dialect of Rome, the name februa was given to those pieces of wool (lanae) given by the rex and the flamen to the pontifices for these rituals and ceremonies of purification. Because of the connection of Juno to these feasts, I am personally more inclined to think that in this context we are dealing with the Flamen Dialis, the supreme head of the cult of Iuppiter Optimus Maximus Capitolinus, mainly because Juno was the wife of Jupiter, in Roman mythology (likewise, Hera is the female consort of Olympian Zeus, the heavenly god of Greek mythology). The connection with Mars and the Flamen Martialis can also be postulated, because of the männerbund character of the Luperci fraternity, a ritual brotherhood of young men bound even in name to the wolf (lupus), the animal sacred to Mars, the old Italic and Latin (ancient Roman) god of war and protector of agricultural fields (known also as Mavors, Mamers, Marmar, even Berber, vide the Cantus Fratrum Arvalium). The direct connection of the Lupercalia with Jupiter remains, however, limited only to the role played by the Flamen Dialis in the preparing of the religious ceremony and ritual (the role of the pieces of wool/lanae given by him and by the Rex sacrificulus to the Pontifices); as to the connection with Mars, it is very small and limited to the general similarity between the ritual confraternity of the Luperci, which imitated the two factions of the proto-Roman war band of Romulus and Remus. (vide the division between the Luperci Fabiani and Luperci Quinctiales). ${ }^{5}$ The ancient Italic god (possibly a deified king or hero, who has become a god in his own right, a counterpart of Pan) Faunus Lupercus is also the divine patron of this feast and so the qualification "Lupercus" added to his original name (i.e. Faunus) makes him the divine protector of the Luperci. It is nevertheless because of the connection of the purification ritual with the goddess Juno, the divine protector of marriages and women in childbirth that we can conclude that the flamen mentioned by Ovid is the chief priest of the cult of Jupiter (Flamen Dialis).

The name februa has been also given to the pinewood wand or twig given to the flaminica, the wife of the flamen. It was a pure branch cut off from a tree, which adorned the head of the priest (or wife of the flamen priest). ${ }^{6}$ The feast is described by Ovid as primarily a purification of men, women, and even of the earth itself. This

${ }^{4}$ Ovid, Fasti II 21-22: Pontifices ab rege petunt et flamine lanas, quis(sic) veterum lingua februa nomen erat. It is clearly stated in this verse that the Pontifices ask for those pieces of wool from the Rex (presumably Rex sacrificulus) and from the Flamen (as we shall see later, the Flamen Dialis, entrusted with the cult of Iuppiter Optimus Maximus Capitolinus).

${ }^{5}$ MastrocinQue 2009, 13.

${ }^{6}$ Ovid, Fasti II 25-30: nomen idem ramo, qui caesus ab arbore pura, / casta sacerdotum tempora fronde tegit. / ipse ego flaminicam poscentem februa vidi,/februa poscenti pinea virga data est. / Denique quandocumque est quo corpora nostra piantur, / hoc apud intonsos nomen habebat avos. - These verses underline the antiquity of this ritual and the purification purpose of the rites involving the februa pinea virga (the pine wand called februa), a purification aiming at the physical bodies of the Roman citizens. The wife of the flamen (the flaminica) asks for this wand (presumably from her husband; or even for her husband, from those who cut it off from the pine tree. The verse's ambiguity allows both interpretations). The nail or pin like leaves of the pine twig adorned the head of the flamen. The unkempt ancestors of the Romans of Ovid's day gave the name februa to this pine branch or twig used by the Flamen and his wife (flaminica) in purification ceremonies. 
becomes clear in the following verse: mensis ab his dictus, secta quia pelle Luperci / omne solum lustrant, idque piamen habent (Ovid, Fasti II 31-32). The verse tells us that the month of February comes from the purification performed by the Luperci with the flayed and cut skin (secta pelle) of the sacrificed goat. We see from these verses that the feast of the Lupercalia was primarily connected with the purification of people, of land, and possibly also of cattle. The ultimate aim of the ritual was to wash away all evil. ${ }^{7}$ It was this belief, according to Ovid, a sacred rite which was ancient in Rome. It originated from the unkempt ancestors (intonsos ... avos) of the Romans of Ovid's day. The third day (15 ${ }^{\text {th }}$ of February) after the Ides of February $\left(13^{\text {th }}\right.$ of February) was the day associated with the sacred ceremonies to Faunus Lupercus (these holy rituals had allegedly been borne to ancient Latium by the Arcadians, according to Ovid ${ }^{8}$ ). Here we find clearly stated the equation between Faunus bicornis and Pan the deus pecoris (the god of cattle, goats, and sheep). This was the moment of the famous running of the naked Luperci through the Eternal City and their beating the women encountered during their run with their leather thongs. The following text represents the connection with Pan and the Arcadian King Evander, and also with domestic animals like mares and sheep (Ovid, Fasti II 277-280): Pan erat armenti, Pan illic numen equarum / munus ob incolumes ille ferebat oves / Transtulit Evander silvestria numina secum / hic, ubi nunc urbs est, tum locus Urbis erat" (My translation, inspired by the Kline translation of Ovid's text: "Pan was there the god of cattle herds and mares / His duty was to drive the sheep safe / Evander has brought his woodland gods with him / Here, where now it is a city, back then was the future town place", in Ovid, Fasti II 277-280).

This practice is clearly stated as being prior to the foundation of the Vrbs. Ovid then explains much more the historical rationale behind the Lupercalia rituals: Inde deum colimus devectaque sacra Pelasgis: / Flamen ad haec prisco more Dialis erat (Ovid, Fasti II 281-282). "We then worship the god and the sacred rituals brought by the Pelasgians: The Flamen of Jupiter was in charge according to ancient custom."

It is therefore clear that, according to Ovid, the most ancient rites of the mythical Pelasgi were involved in the worshipping of the god patronizing those religious feasts. ${ }^{9}$ These two verses also explain that it was the flamen Dialis, the Roman priest,

${ }^{7}$ Ovid, Fasti II 35-36: Omne nefas omnemque mali purgamina causam / Credebant nostri tollere posse senes "Our ancestors believed that purification rituals could remove every inauspicious thing and the cause of every evil" (my translation).

${ }^{8}$ Ovid, Fasti II 267-272: Tertia post Idus nudos aurora Lupercos, / aspicit, et Fauni sacra bicornis eunt, / Dicite, Pierides sacrorum quae sit origo, / attigerint Latias unde petita domos. / Pana deum pecoris veteres coluisse feruntur / Arcades, Arcadiis plurimus ille iugis. "The third dawn (day) after the Idus sees the naked Luperci, and off they go to the rituals of the Two Horned Faunus, Speak, O Pierides (Muses), what is the origin of these sacred rites, wherefrom the demanded rituals have reached the Latin hoseholds? It is said that the Arcadians of old had venerated Pan the god of the sheep herd, He is very often on the Arcadian (mountain) yokes." (my translation, inspired by the Romanian translation of Ovid's verse by NĂDEJDE, NĂDEJDE 507 s.v. Plurimus).

${ }^{9}$ Presumably Faunus Lupercus, if one thinks deum in the verse as the Accusative singular form of deus, dei, and not as the poetic plural Genitive form of the same noun: deum instead of deorum for metrical reasons, making therefore only sacra devectaque [deum i.e. deorum, "of the gods"] the direct object of the verb colimus. I am rather personally inclined to see here the deum as an Accusative singular case of deus, dei, meaning basically the god Pan (Acc.sg. Pana) or Faunus Lupercus (Acc.sg. Faunum 
involved in the celebration of the Lupercalia. The ritual running by the Luperci through the Eternal City, descending from the Palatine hill was seen as pleasant to the god Faunus Lupercus, who once did the same thing and performed the office of the youthful Luperci runners. ${ }^{10}$ The reasons for the nakedness of the young Luperci allegedly was (at least according to Ovid, Fasti II 287-288: ipse deus nudus nudos iubet ire ministros; / nec satis ad cursus commoda vestis erit "the god himself nude commands his servants to go nude themselves; the cloak will not be fit enough for running") the facility of movement and quickness implied by nudity and also a means to avoid errors about their true fecundating ritual function; any mistake about the Luperci's true role was averted by their lack of (almost) any clothing (it is a loincloth of goat skin as the only garment possibly worn by the Luperci). ${ }^{11}$ The rite of the Luperci was apparently an age-old rite, a rite that had been performed in the almost forgotten times before the birth of Jupiter (Zeus to the ancient Greeks), probably since the Golden Age (Aurea Aetas) of Saturnus (K@óvos/X@óvos) by the Arcadians. ${ }^{12}$ Finally, the sacrifice of a female goat to Faunus-Lupercus-Pan (the god represented in the form of a half-man and half-male goat, with human shape but with horns, hooves, and facial hair like a male goat in Greek and Roman sculpture, painting, and mosaics) is clear in verse 361

Lupercum). The sacra devectaque deum becomes thus the object of the verb colimus in this verse ("we cultivate/worship the god and the sacred rituals brought from abroad by the Pelasgians").

${ }^{10}$ Ovid, Fasti II 283-288: Cur igitur currant, et cur (sic currere mos est) / nuda ferant posita corpora veste rogas? / Ipse deus velox discurrere gaudet in altis / montibus, et subitas concipit ipse fugas: / ipse deus nudus nudos iubet ire ministros; / nec satis ad cursus commoda vestis erit "Why then should they run, and why (because the custom is running) ask you they bear their bodies naked with the clothes put aside? The god himself enjoys fast running in the high mountains and himself does sudden runnings, the god himself nude commands his servants to go nude themselves; the cloak will not be fit enough for running". - It appears here as a clear case of imitatio dei (i.e. Fauni Luperci): the once-naked god Pan (Faunus Lupercus) has divinely ordained that his human servants follow his example and run naked downhill and fustigate the nubile girls and fertile young women, in order to enhance their present and/or future fertility (to improve fecundity and possibly also to ease the pains of childbirth, which is already an "encroaching" by Faunus into the domain presided over by Juno in her quality of Iuno Lucina, the goddess protecting pregnancy and mother and child at birth). In these verses, Ovid underlines the nudity of Luperci and after that he introduces the aition of Hercules and Omphale. Faunus, exactly like his ancient Greek counterpart Pan, dwells in the bushes and the nearby hills, but is linked by the Lupercalia with the reproduction of the citizen body of Rome. Vide MASTROCINQUE 2009, 6-7 for the Italic cults of Bona Dea and of other Italic goddesses like Marica, Pomona etc.: it is mainly about the role of the Bona Dea cult in the religious rituals of sexual initiations of young girls. It is also the cult of Faunus and of his wife (or sister) Fauna which plays an essential role in the Lupercalia. Iuno Caprotina, Minerva, and Stimula are Italic goddesses concerned with the life period of young nubile girls before their marriage, while Bona Dea (identified with Fauna, the female counterpart of Faunus Lupercus) as well as other Italic goddesses (Pomona, Marica, Vesuna, Cavatha) were female deities involved in the transition between unmarried girl and wife (vide MASTROCINQUE 2009, 6-8).

${ }^{11}$ Two teenage boys (Luperci) were anointed by the Pontifex with goat's blood (the ritual sacrificial knife was cleaned with the wool/lana, which then anointed the foreheads of the two young Luperci, who were immediately supposed to smile or laugh), vide MASTROCINQUE 2009, 13-14.

${ }^{12}$ Ovid, Fasti II 289-292: ante Iovem genitum terras habuisse feruntur / Arcades, et luna gens prior illa fuit. / Vita feris similis, nullos agitata per usus: / artis adhuc expers et rude volgus erat "Before the birth of Jupiter the lands, it is said, had been inhabited by the Arcadians, and the moon was before that people, their life was beast like, unstirred by any customs to such degree was the people ignorant and simple (unpolished by civilisation)." 
of the second book of Ovid's Fasti (Ovid, Fasti II 361: cornipedi Fauno caesa de more capella). ${ }^{13}$

The nakedness of the Luperci is reminiscent of the ritual nudity of Romulus, Remus, and their companions and brothers in arms. ${ }^{14}$ The young warriors and shepherds around the Twins (Romulus and Remus) were deemed to have been the first Roman Luperci (although the cult to the god Pan-Faunus appeared to have been previously introduced by King Evander and his Arcadians). ${ }^{15}$

Let us now move past Ovid and see the information conveyed by Late Antiquity writers such as Arnobius and Macrobius about Juno, the Lupercalia, and their possible relationship. We are dealing here with erudite Roman scholars from the late $4^{\text {th }}$ and early $5^{\text {th }}$ centuries after Christ, who tried to create a synthesis of the Polytheistic Graeco-Roman (or Greek-Latin) mythologies and cultic rituals and to convey them to future generations (although they were most probably aware of the triumph of the new religion, Christianity, in what was left of the Roman Empire during the $5^{\text {th }}$ century after Christ). More than the old polytheistic Roman religion, they (Arnobius and Macrobius) were keen to preserve the old culture and civilization of ancient Rome, something of the ancient Roman spirit, as it was recorded in the cultural memory of ancient pagan rites, rituals, and feasting ceremonies that would endure for centuries to come in the rural areas (some even up to our own day). Time and time again, however, these rites were again denounced as heathen or, on the contrary, were adopted and adapted by the Christian Church of Rome and of Constantinople, when suited to the Evangelization needs of the lay people. As boys, both Arnobius and Macrobius would have witnessed first-hand the last priests of the ancient Roman religion performing their non-Christian rituals and worshipping the old gods and goddesses of ancient Greece and Rome. They both saw the rise to power of Christianity as the only official religion of the Roman Empire. Their antiquarian effort was probably intended to preserve the cultural memory of the old Roman aristocracy. The work of Macrobius is entitled Saturnalia, a title clearly intended to evoke in the mind of the reader and hearer the famous pagan Roman

\footnotetext{
13 "Being by custom a small goat sacrificed to the hooved feet Faunus" (Ovid, Fasti II 361: cornipedi Fauno caesa de more capella).

${ }^{14}$ Ovid, Fasti II 365-366: Romulus et frater pastoralisque iuventus / solibus et campo corpora nuda dabant "Romulus and his brother and the herdsmen youths/ exposed their nude bodies to the sun rays in the field".

${ }^{15}$ Vide supra Ovid, Fasti II 277-280 about Faunus the god of cattle herds, mares, and sheep. The verses of Ovid (Fasti II 367-368) describes the athletic activities of Romulus, Remus, and their companions (the band of young warriors and herdsmen, which followed the Twins and founded Rome): vectibus et iaculis et misso pondere saxi / bracchia per lusus experienda dabant. The activities of cattle rustling (so prominent in many Indo-European mythologies and epic heroic poems, to quote only the ancient Greek myth of Heracles and the cows of Geryones/ the 10th Labour of Heracles as well as the Irish Gaelic epic story of Táin Bó Cualnge; vide GuYONVARCH (ed.) 2009, passim; MARKALE 1971, passim) mentioned immediately after in the following verses of Ovid's Fasti II 369-378 that qualifies the praedones who stole the herdsman's cattle as the enemy vanquished by Remus and his Fabii, the young warriors who eventually eat the oxen' and cows' meat. Romulus and his Quintilii arrived too late at the feast and were left with the cattle bones deprived of flesh (hence perhaps the origin of the Latin proverb tarde venientibus ossa): they laughed and their laugh (of Romulus and of his Quintilii warriors) became the symbolic inheritance of the Luperci.
} 
Feasts of December. His (Macrobius') intention is the defense and preservation of the old Greek and Roman polytheistic religion, with all its gods and goddesses, demi-

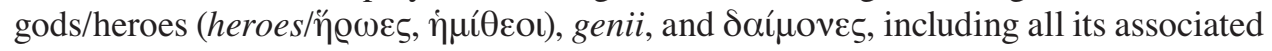
mythology and ritualistic pageantry. On the other hand, Arnobius' work bears the title Adversus Nationes libri VII: it is an apologetic work, written in the spirit of Christian patristic writings. As opposed to Macrobius' intention, Arnobius combatted and strenuously fought against the ancient polytheistic Roman religion. He was nonetheless keen to preserve the culture and civilization of ancient Rome (in that respect, his intention was identical with Macrobius' idea), but (contrary to Macrobius) devoid of the ancient gods of Rome (in other words, a Roman civilization deprived of the spirit and values of its own culture).

Macrobius' Saturnalia (written sometime during the first quarter or the first half of the $5^{\text {th }}$ century after Christ, perhaps around 430 AD?) is a gold mine of information about elements of ritual and about links between astronomy, gods, calendar, and the

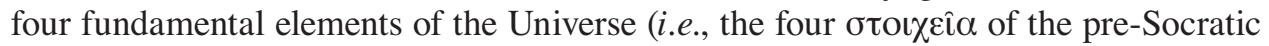
Greek philosophers: air, water, fire, and earth). The goddess Juno appears here to be connected with the element of air, with the month of June (Iunius mensis) in the Roman calendar (a month which in Babylonian-inspired European Astrology is mostly under Air, the zodiac sign of the Gemini), and with the days called Kalendae in the ancient Roman system of reckoning time. ${ }^{16}$ The gods, who are protectors of all beginnings,

\footnotetext{
${ }^{16}$ Macrobius, Sat. I 9. 10-18; I 10-12: ... in sacris quoque invocamus Ianum Geminum, Ianum Patrem, Ianum Iunonium, Ianum Convivium, Ianum Quirinum, Ianum Patulcium et Clusivium, cur Geminum invocamus supra iam diximus, Patrem quasi deorum deum, Iunonium quasi non solum mensis Ianuarii sed mensium omnium ingressus tenentem; in dicione autem Iunonis sunt omnes Kalendae, unde et Varro libro quinto Rerum Divinarum scribit Iano duodecim aras pro totidem mensibus dedicatas. - We encounter here a most interesting connection between Ianus Bifrons (or Geminus), the gods of gates and doors, of entrance and exit points (in both space and time) and Juno, connected with the beginnings of months and therefore with the Kalendae and with the deity protecting the beginning of the Roman calendar, Ianus (the eponymous character for the first month of the year, January/Ianuarius mensis), who also patronized the beginning of every month of the Roman astronomic year. Janus protected the gates and doors of cities, temples and houses, while both Janus and Juno patronized the beginning of every month of the Roman calendar. Moreover, to Janus it was also dedicated the first month of the Roman year, which is called until today the month of January (Ianuarius mensis). Janus is seen by Macrobius as almost "the father god of all the gods" (Patrem quasi deorum deum) and has many epithets: Geminus, Pater, Iunonius, Convivius, Quirinus, Patulcius, and Clusivius. Vide for the connection between Juno and the month of June, between the Kalendae of June and the dedication of the temple of Iuno Moneta also Macrobius, Sat. I 12. 30-33: Iunius Maium sequitur, aut ex parte populi, ut supra diximus, nominatus, aut, ut Cingius arbitratur quod Iunonius apud Latinos ante vocitatus, diuque apud Aricinos Praenestinosque hoc appellatione in fastos relatos sit adeo ut, sicut Nisus in commentariis fastorum dicit, apud maiores quoque nostros haec appellatione mensis diu manserit, sed post detritis quibusdam litteris ex Iunonio Iunius dictus sit. Nam et aedes Iunoni Monetae Kalendis Iunii dedicata est, non nulli putaverunt Iunium mensem a Iunio Bruto qui primus Romae consul factus est, quod hoc mense, id est Kalendis Iuniis, pulso Tarquinio sacrum Carnae deae in Coelio monte voti reus fecerit. Hanc deam vitalibus humanis praeesse credunt. - In this text fragment it appears that in Latium, in Aricia/Aricium (present day Arricia) and Praeneste (present day Palestrina), the mensis Iunius was also called or known as Iunonius (it was only after the erasing of a few letters that from Iunonius it has been arrived to Iunius). The temple (aedes) of Juno Moneta was dedicated (dedicatio or consecratio) at the Kalendae of June. No few ancient Romans believed that the name of the month of June (Iunius mensis) came from the gentilicium or nomen gentile
} 
in both space and time, appear, according to Macrobius, to have been both Ianus and

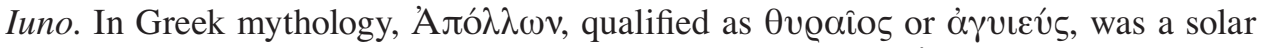
god associated with transit points (especially gates of cities; 'EQ $\mu \hat{\eta} \varsigma$, the brother of A $\pi$ ó $\lambda \lambda \omega v$, was the protector of crossroads), according to Macrobius. ${ }^{17}$ Ianus (i.e., the Italic and Roman-Latin god Janus, a deity of gates, portals, and doors, and of entrances and exits), writes Macrobius, has the same meaning as the Greek @v@oîos (an epithet of Apollo). This could lead to a rapprochement between the age-old Italic god Janus and the Roman aspect of the Graeco-Roman solar god Apollo (the Olympian Greek god Apollon of Delos and Delphi). ${ }^{18}$ The goddess Diana (the Greek 'A $\varrho \tau \varepsilon \mu \iota \varsigma$ ) in her aspect of Trivia (the triple Hecate) was also a female deity patronizing roads and crossroads, along with her brother Apollo and step-brother Hermes (Mercurius). The days called the Idus (the Ides of every Roman month), which marked the middle of the month and basically cut every month in two, were (if we choose to believe Macrobius, who is, however, a very late informant on the ancient religion of Rome) under the protection of Jove (Iuppiter) and so were therefore also the Lupercalia (a feast situated mainly under the patronage of Faunus Lupercus and, as we shall later see, under the aegis, so to say, of Juno). ${ }^{19}$ Macrobius, in the fragment quoted below, considers Juno and

of Iunius (from Marcus Iunius Brutus the one who contrived the expulsion of the last king of Rome, the Etruscan Tarquinius II Superbus; furthermore, he referred to the sanctuary of the Dea Carna on the Mons Caelius in Rome). The Dea Carna, whose sanctuary was on the Mons Caelius, was the deity in charge with the preservation of the human vital organs or vital functions of the human body (vitales) in the ancient Roman religion, according to Macrobius.

${ }^{17}$ Macrobius, Sat. I 8. 8-12; I 9.1 ssq.: Nigidius quoque refert, apud Graecos Apollo colitur, qui

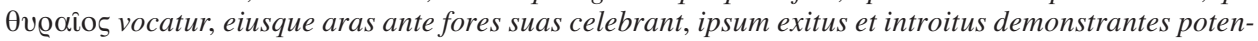
tem: idem Apollo apud illos et Ayvicús nuncupatur, quasi viis praepositus urbanis: illi enim vias quae

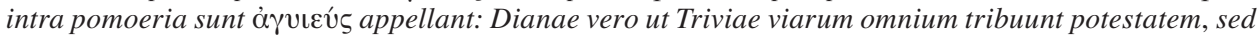

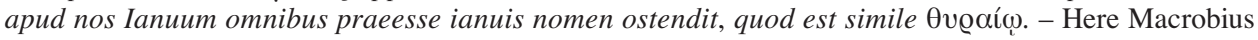
refers perhaps to Nigidius Figulus' authority, the neopythagoreic philosopher, mathematician, and astronomer from the time of Augustus, who says that Apollo was the protector of highways both outside the city

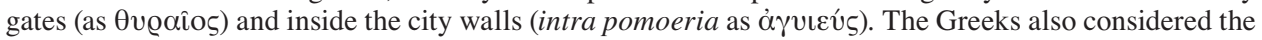
goddess Artemis (Diana Trivia to the Romans) as the patron and protector of all roads (like his brother Apollon protected the city gates and doors of houses), while to the Romans the god Janus presided over gates and doors, over all entrance and exit points, beginnings and ends of roads in both space and time.

${ }_{18}$ DUMÉZIL 1999, passim (esp. 22-36).

${ }^{19}$ Macrobius, Sat. I 15. 17-19: Nobis illa ratio nominis vero propior aestimatur, ut idus vocemus diem qui dividit mensem. Iduare enim Etrusca lingua dividere est, unde vidua quasi valde idua id est valde divisa, aut vidua id est a viro divisa, ut autem idus omnes Iovi, ita omnes Kalendas Iunoni tributas et Varronis et pontificalis adfirmat auctoritas, quod etiam Laurentes patriis religionibus servant, qui et cognomen deae ex caerimoniis addiderunt, Kalendarem Iunonem vocantes, sed et omnibus Kalendis a mense Martio ad Decembrem huic deae Kalendarum die supplicant. - It is clear that there is a strong bound between Jove and the Idus on the one hand, and Juno and the Kalendae on the other, and Macrobius held here Varro as the Roman antiquarian authority. Macrobius then continues: Romae quoque Kalendis omnibus, praeter quod pontifex minor in curia Calabra rem divinam Iunoni facit, etiam regina sacrorum, id est regis uxor, porcam vel agnam in regia Iunoni immolat, a qua etiam Ianum Iunonium cognominatum diximus, quod illi deo omnia ingressus, huic deae cuncti Kalendarum dies videntur adscripti, cum enim initia mensium maiores nostri ab exortu lunae servaverint, iure Iunoni addixerunt Kalendas, lunam ac Iunonem eandem putantes: vel quia luna per aerem meat, unde et

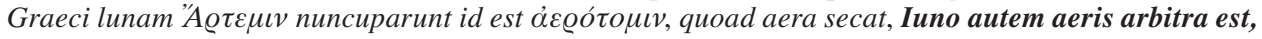
merito initia mensium, id est Kalendas, huic deae consecraverunt. (Macrobius, Sat. I 15.17-19). - We 
the threefold aspects of the Moon goddess (Diana/Artemis, Hecate/Trivia, and Luna/ Selene) as being essentially one and the same deity, linked to the fundamental cosmic element of Air (aer/àn@). The beginnings of every month of the oldest Roman calendar (of ten months, from March to December, January and February being supernumerary months, in order to combine the solar and lunar calendars and merge them into one), the Kalendae, were under the special patronage of Juno. Every beginning in time and space appears to have been also under the divine protection of the god Janus (Ianus), and from here his epithet Iunonius, that would have been otherwise inexplicable. Ianus Bifrons or Ianus Geminus, Iunonius, Quirinus etc. appeared to Macrobius as a Roman counterpart to the Greek solar god and protector of city gates, Ađ

According to the same Macrobius, the Idus noun and the verb Iduare comes in Latin from Etruscan, where iduare meant to divide (dividere). We cannot verify Macrobius' assumption, but his etymology, deriving the Latin word vidua (widow) from the expression valde idua (very separated), is questionable, to say the least (the Latin word vidua, as well as English widow, German witwe, Slavic vedova and so on and forth, is and are perfectly explainable on Indo-European linguistic grounds, instead on obscure Etruscan etymology). ${ }^{20}$ His testimony is, however, based on the authority of the Roman antiquarian Varro and of the Roman pontifices. More interesting are the connections made by Macrobius between Jupiter as god and daylight (lux): in Macrobius' interpretation of Roman mythology (or rather polytheistic and henotheistic theology) grounded in ancient Greek metaphysics, Jove is not only reigning in Heaven (Caelus, himself an age-old divinity of Heaven, much older than Iuppiter, is equated in Greek mythology to Oủoavós; and Zعús and Iuppiter were seen by educated Romans as different names of the same sky god or celestial king of the gods); he is also the light of day (lux or rather lumen diei). ${ }^{21}$

encounter here the most interesting links between Greek and Roman mythology, between Janus and Juno on the one hand, and between Juno and the Moon goddess (Luna/Selene or Diana/Artemis/Hecate) on the other. Juno, the Moon, and the Air appeared essentially as intimately bound to each other; moreover, they are interconnected as different names (and aspects?!) of the same ultimate divine being. Juno appears to be inextricably linked to the beginning of every month of the year.

${ }^{20}$ WALD-SLUŞANSCHI-BĂLTĂCEANU 1987, 300.

${ }^{21}$ Here we give the whole, somewhat long, quotation from Macrobius, Sat. I 15. 14-16: Iduum porro nomen a Tuscis, apud quos is dies Itis vocatur, sumptum est. Item autem illi interpretantur Iovis fiduciam. Nam cum Iovem accipiamus lucis auctorem, unde et Lucetium Salii in carminibus canunt et

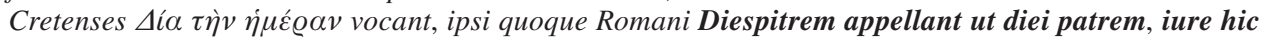
dies Iovis fiducia vocatur, cuius lux non finitur cum solis occasu, sed splendorem diei et nocte continuat inlustrante luna, diem igitur, qui vel nocturnis cavet tenebris, Iovis fiduciam Tusco nomine vocaverunt, unde et omnes idus Iovis ferias observandas sanxit antiquitas. Alii putant Idus, quod eo die plena luna videatur, a videndo vidus appellatos, mox litteram v detractam, sicut contra, quod Graeci ideîv dicunt, nos v littera addita videre dicimus. - We therefore have here two or even three possible etymologies for Idus, one from the Etruscan Itis, another from the Latin verb videre (ancient Greek i̇eîv), and this is finally explained by the etymology of Iuppiter or Iupiter, stemming from Diespiter (Diei pater, the Day's Father), an etymology surprisingly modern and correct, if we judge with the Vedic parallel of Dyaus Pitar, a parallel unavailable to Macrobius (vide WALD-SLUŞANSCHI-BĂLTĂCEANU 1987, 279). There is also present the rationalistic explanation by Macrobius that the light of the sun during the day is continued ("reflected", we would say) by the moon's light during the night, and the Idus falls every time during the full moon. Macrobius continues and gives a Greek etymology for the word Idus and, anew, an 
We end this analysis of late Latin literary sources on the ancient Greek and Roman religion with Arnobius'Adversus Nationes libri VII. Here he gives an overview of ancient Roman religion from the point of view of a new convert to Christianity, a Christian who is polemic against the polytheistic cults of ancient Rome, but who has nevertheless a deep knowledge of the Graeco-Roman mythological lore. In fact, Arnobius (Adv. Nat. III 23. 20-22) presents Juno as the goddess protecting childbirth; but despite her protection, writes the Christian author, thousands of mothers die on a daily basis giving birth to their children or soon afterwards, from puerperal fever. ${ }^{22}$ The link between Juno and the Lupercalia, although not explained by Arnobius, is nevertheless mentioned in a subsequent passage of his text (Arnob. Adv. Nat. III 30. 14-15: nulla Februtis Populonia Cinxia Caprotina). This is an enumeration of Juno's epithets, Februtis being perhaps an epithet of Juno linked with the month of February and with the Lupercalia. This shows that Arnobius had knowledge of the connection between one aspect of the Juno cult and the Lupercalia ceremonies and, either due to his lack of deeper knowledge about these things, or rather because of the polemical character of his work; he did not deepen his analysis further. There are numerous short references to Juno scattered here and there in Arnobius' work, but he does not try to go further in the analysis of the cult of Juno (because this was not the purpose of his writing), and therefore he only mentions the functions of the various gods and goddesses of ancient Greece and Rome and elements of their myths and rituals performed for their worship, religious elements suited to his polemic anti-pagan task. He has, however, transmitted to us a lot of elements concerning the rites and myths of the ancient gods, of religious ceremonies and rituals, and the Greek philosophical theories about the gods and the four elements of nature, the connections between gods and astronomy, and so on and so forth.

Apart from the goat skin called amiculum Iunonis, and the fertility ritual for Roman women by the agency of the Luperci's beating them with leather thongs, at first sight there appears to have been little to no connection at all, between the Lupercalia and the goddess Juno, at least with regard to the ancient Roman calendar and the gods assigned as divine patrons of the different days of the month. Things, however, are not so simple, but nevertheless this is only an illusion due to partial ignorance of ancient Roman religion. The whips made out of leather thongs used by the Luperci were expressis verbis called the amiculum Iunonis (the garment or cloak of Juno) not without reason, as we shall see below.

In Latin, the word amiculum stands for garment, cloak, or piece of cloth, while the amicula Iunonis (the leather thongs of the sacrificed goat's skin, with which the Luperci made whips in order to beat the young women encountered during their run down the Palatine hill) are specifically connected with the Lupercalia. This fact makes

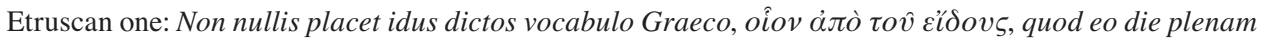
speciem luna demonstraret. Sunt qui aestiment idus ab ove iduli dictos, quam hoc nomine vocant Tusci et omnibus idibus Iovi immolatur a flamine (vide supra).

${ }_{22}$ Arnob. Adv. Nat. III 23. 20-22: puerperiis Iuno praeposita est et auxiliatur genetricibus fetis: et matrum intereunt cur cotidie milia parricidalibus nixibus interemptae? 
the entire discussion on this topic much more complicated. We know that there was an aspect of Juno, Iuno Caprotina, clearly related through name with the goat, while another hypostasis of Juno, the so-called Iuno Sospita, was dressed with an amiculum Iunonis made out of goat skin. Iuno Sospita, moreover, links the warlike aspect of this goddess with her fertility aspect. Given these facts, which one eventually explains the connection of Juno with the Lupercalia? The main function of Juno was the protection of lawful marriage; the rightful wedlock, the bride, the wife, and the pregnant married woman were among Juno's main divine responsibilities. The process of giving birth was also under Juno's shield, so to speak (vide the Greek Hera Eileithyia). The epithets of Juno and her divine functions are numerous (Regina, Moneta, Sospita, Caprotina, Curritis, and so on). The function of goddess protecting legal marriage and the legitimate offspring of the Roman citizen body is essential to Juno. Marriage was only the last step in the initiation of the young Latin girls into adulthood and sexuality. The goddess Bona Dea (identified with Fauna) presided over this transition process (whose religious feast, reserved only to women, at least in theory, took place on the $1^{\text {st }}$ of May) as well with the Lanuvium or Lavinium aspect of Juno (the Iuno Sospita or the Hera Argolis, according to Propertius' poem IV 8. 3-14 and Aelianus' Historia Animarum XI 16) connected with the snake which eats a ritual cake only from the pure hands of a virgin maiden. ${ }^{23}$ In the Greek world, the caves of Pan and the melody of his syrinx (Pan's flute) proved the virginity of Greek maidens. ${ }^{24}$

In concluding our analysis, we cannot say that Juno and the Lupercalia ceremonies were linked in any way other than in the performing of a fertility ritual; but this very link was essential to the whole character and purpose of the Lupercalia ceremony and defined the ritual as such. The amiculum Iunonis was only an instrument, an element of this religious ritual. The feast of the Lupercalia was also linked to Jove by the very fact of being located in the middle of the month of February, and with Faunus Lupercus (Pan) as the primary deity presiding over this religious feast. The Luperci fraternity has a mythical association with Mars and with Romulus-Quirinus, being a brotherhood of young men (Männerbund); their very name (luperci) is reminiscent of the wolf (lupus), an animal consecrated to Mars (as well as with the Lupercal natural cave on the slope of the Palatine hill and therefore with Romulus, Remus, and the beginnings of Rome). Romulus himself (as a true son of Mars) during his youthful years was also a war-band leader of the young men (herdsmen, hunters, and exiled youths), a war band which constituted also the nucleus of the young men who founded

${ }^{23}$ MASTROCINQUe 2009, 10-11.

${ }^{24}$ MastrocinQue 2009, 11-12. Vide Achilles Tatius' Clitophon et Leucippe VIII 6. 9-11 apud Mastrocinque 2009, 11, n. 31 and the legend of Pan and the nymph Syrinx, as well as the cession by Pan of his cave to Artemis, were maiden (i.e. unmarried) girls proved their innocence when accused of not being virgins anymore. Pan was to the Greeks the counterpart of the Italic Faunus. For the symbolic objects used in the rituals of the Lupercalia and of the Bona Dea respectively (the leather whips of the Luperci and the box with ritual objects in the rituals of the Bona Dea), vide MASTROCINQUE 2009, 13-15. As for the Lupercalia being also a ritual reenactment of the episode of Remus' Fabii and Romulus' Quintilii vide Ovid, Fasti II 379-380: forma manet facti: posito velamine currunt, / et memorem famam quod bene cessit habet. 
Rome. Romulus in his deified aspect is known as Quirinus. The Luperci ritual is also consistently linked (because of Faunus Lupercus, son of Picus, and grandson of Saturnus, according to one mythical genealogy; Faunus as the father of King Latinus, Aeneas' second father-in-law, according to Vergil's Aeneid VII 37-106), according to Ovid, to King Evander and his Arcadian immigrants on the Palatine hill (who identified Faunus with their god of wild nature, the Greek hooved and goat-horned Pan). It is an age-old rite, older than Rome itself and is a reminiscence of the Golden Age (Aurea Aetas) of Saturnus. ${ }^{25}$

Dan-Tudor Ionescu

\section{BIBLIOGRAPHY}

DuMÉZIL, G. 1993: Mit şi Epopee [Mythe et Épopée/Myth and Epics; Romanian translation by G. Creția, F. Băltăceanu and D. Sluşanschi]. Vols. I-III. Bucureşti DuMÉZIL, G. 1998:Zeii suverani ai Indo-Europenilor [Les Dieux souverains des IndoEuropéens/The Sovereign Gods of the Indo-Europeans; Romanian translation by P. Cretia]. Bucureşti

DumézIL, G. 1999: Cele Patru Puteri ale lui Apolo şi alte eseuri Douăzeci şi cinci de schite in mitologie [Apollon sonore et autres essais/The Four Powers of Apollo and Other Essays. Twenty Five Essays on Mythology; Romanian translation by G. Anania]. Bucureşti

Guyonvarch, Christian-J. (ed.) 2009: L’Epopea di Cuchulainn. La Razzia delle Vacche di Cooley. Roma

HÄUSSLER, R. 1995: Hera und Juno. Wandlungen und Beharrung einer Göttin. Stuttgart

SHIELDS, E. L. 1926: Juno. A Study in Early Roman Religion [Smith College Classical Studies 7]. Northampton, MA

MARKALE, J. 1971: L'Épopée celtique d'Irlande. Paris

Mastrocinque, A. 2009: Bona Dea and Marriage Rituals in Rome and Ancient Italy. Heidelberg-Messina-Firenze (electronic version)

NĂDEJDE, I. - NĂDEJDE GESTICONE, A. s. a.: Dicționar Român-Latin Complectl Romanian Latin Complete Dictionary. Bucharest

WALD, L. - SLUŞANSCHI, D. - BĂLTĂCEANU, F. 1987: Introducere în Studiul Limbii şi Culturii Indo-Europene [Introduction in the Study of Indo-European Language and Culture]. Bucureşti

${ }^{25}$ HÄUSSLER 1995, 26 ssq.: Juno was intimately connected with the Calendar, but she bore also a lot of surnames or epithets (reflecting her divine functions and aspects) such as Regina (queen, the wife of Jove), Sospita, Moneta, Caprotina, Curritis, Cinxia, Pronuba, Lucina, and so on. For the Greeks, we have Hera or Here Eileithyia, Geneteira, Potnia, Boopis, and so forth, sometimes corresponding to the epithets and functions of the Roman Juno. Vide et SHIELDS 1926, passim. For Faunus, Hercules, and Mars as city founders and people founders vide MASTROCINQUE 2009, 18, 25, 26-27 (the role of Dionysus-Liber Pater in the nuptial ritual). 
